(昭和 35 年 7 月 29 日受理)

ポリビニルアルコールとビニルピロリドン系重合物との混合紡糸

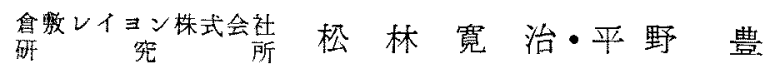

\title{
THE SPINNING OF A POLYMER BLEND CONSISTING OF POLYVINYL ALCOHOL AND A POLYMER CONTAINING VINYL PYRROLIDONE UNITS
}

\author{
By Kanji Matsubayashi and Yutaka Hirano
}

(Research Laboratory, Kurashiki Rayon Co. Ltd., Kurashiki City, Okayama Prefecture, Japan)

In order to improve the dyeability of vinylon, the wet spinning of a polymer blend consisting of polyvinyl alcohol and a polymer containing vinyl pyrrolidone units, such as polyvinyl pyrrolidone and saponified or unsaponified vinyl acetate-vinyl pyrrolidone copolymer was carried out, and the fiber was subsequently heat-treated and acetalized to make the fiber resist to boiling water. Consequently, the fiber having improved dyeability with several dyes such as direct dyes, sulphur dyes and vat dyes, similar to that of cellulosic fibers, was obtained. The effect of blending of polyvinyl pyrrolidone may be explained by the affinity of the dye for polyvinyl pyrrolidone and by the known changes in the cross sectional structure and in the internal fine structure due to the polymer blending. The fiber may be suitable for blending with cellulosic fibers.

By hot-drawing the wet-spun fiber containing polyvinyl pyrrolidone, followed by heat-treatment and formalization, the fiber having a relatively higher stiffness and the improved dyeability was obtained. The fiber shows the stiffness-dpeabillity relation similar to that of a cotton fiber, so the fiber seems to be suitable for blending with cotton.

(Received July 29, 1960)

\section{1. 緒言}

ビニロンの染色性を改良するためボリビニルアルコー 儿(PVA) 誘尊体をはじめ, その他の水溶性重合物を PVA と混合紡系古る試质はすでに数多く行なわれてお

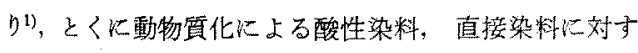
る染色性の改良てはかなりの成果が光られている。しか しせルロース瀻維めるいはビニロンの場合でも堅る5染 色比㥀接染料では不满足で硫化，建染雨染料が広く使 用されており，ビニロンのこれらの染料に対する染色性 を向上させることる重要な問題である。とこらてボリビ ニルピロリドン (PVP) は各種染料とくに硫化, 建染両

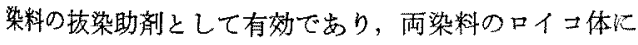

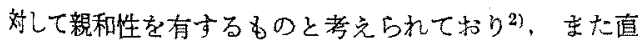
接染料，酸性染料などに対してb親和性を示すことが知

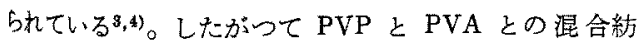
級よりこれらの染料に対するビ二ロンの染色性を向上 させらることが期待される。また永峯ら゙はビニルピロ
リドン（VP) と酢酸ビニル（VAc）との其重合につ! て，また共重合ケン化物の瀻維の染色性についても報告

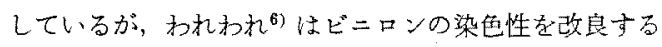
ためPVPはたはVPとVAcとの共重合物，あるい

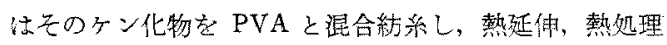
およびアセタール化を行ない，染色性をはじめその他の 諸性質を測定した。その結果ほぼ所期の目的が達せら

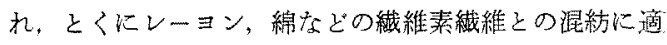
寸ると考兄れるどニロンをらることができたので， こ れらの寒験結果について報告する。

\section{2. 実 験 方 法}

\section{2-1. VP系重合物}

PVP General Aniline \& Film 社製品を用いた （第 1 表）、VPは方販品を、VAc は当社製のものを蒸留 後使用した。共重合（塊状重合）拉よびアルカリルン化 を行なつた結果をそれをれ第 2 表，第 3 表に示した。

\section{2-2. 混合紡糸および效処理}


第 1 表 PVP 試 料

\begin{tabular}{|c|c|c|c|c|}
\hline$K$ & 值 & $30^{\circ} \mathrm{C}$ 水 中 & $\bar{p} *$ & $k^{\prime}$ \\
\hline & 30 & 0.0210 & 193 & 0.556 \\
\hline & 60 & 0.0915 & 2480 & 0.407 \\
\hline & 90 & 0.1330 & 4420 & 0.396 \\
\hline
\end{tabular}

* K. Dialer, K. Vogler の式 [Makromol, Chem., 6, 191 (1951)]

$[\eta]=6.45 \times 10^{-5} \mathrm{M}^{0.58}$ (溜度 $\mathrm{g} / l, \mathrm{M}$ 分子量)に上 つた。
$\%$, 浴比 $50: 1,60^{\circ} \mathrm{C}, 1 \mathrm{hr}$ 。

\section{2-4. 耐熱水性, 機械的性貿}

耐熱水性注既報7) と同じ方法に上り測定した。強伸度 はマッタンジー引張試験機により，一定伸度に対する荷

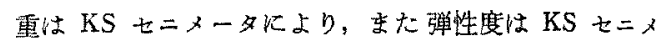
一タを用いてくり返し洗要により，いずれも RH $65 \%$ ， $20^{\circ} \mathrm{C}$ の票染状態が測定した。

\section{2-5. 染色 法}

主として酸性染料として Acid Brilliant Scarlet $3 \mathrm{R}$ (C. I. Acid Red 18) (A.Sc) 4\%, 硫酸 $2 \%$ ，敊硝 10

第 2 表 VAc とVP との共重合

共重合: $\mathrm{N}_{2}$ 置换, $60^{\circ} \mathrm{C}$

\begin{tabular}{|c|c|c|c|c|c|c|c|c|c|c|}
\hline \multicolumn{3}{|c|}{ 重 合 条 件 } & \multicolumn{2}{|r|}{ 㚘 } & 重 & \multicolumn{2}{|l|}{ 物 } & \multirow[b]{2}{*}{ 精 } & \multirow[b]{2}{*}{ 製 } & \multirow[b]{2}{*}{ 法 } \\
\hline $\begin{array}{c}\mathrm{VP} / \text { 笛量体 } \\
(モ ル \%)\end{array}$ & $\begin{array}{c}\text { 重合開始绪* } \\
\text { 单量 } \\
(\%) \\
(\%)\end{array}$ & $\begin{array}{c}\text { 時 閻 } \\
(\mathrm{hr})\end{array}$ & $\begin{array}{l}\text { 重合絜 } \\
(\%)\end{array}$ & $\begin{array}{l}\mathrm{N} \\
(\%)\end{array}$ & $\mid \begin{array}{c}\mathrm{VP} / \text { 共重合物 } \\
(\text { 土小\%) }\end{array}$ & $\begin{array}{c}{[\eta]} \\
30^{\circ} \mathrm{C} \text { 水中 }\end{array}$ & $k^{\prime}$ & & & \\
\hline 37 & 0.005 & 31 & 46.4 & 8.63 & 62.8 & 0.1050 & 0.440 & 流水中 & & \\
\hline 5 & 0.02 & 6 & 62.3 & 1.23 & 7.7 & - & - & $\begin{array}{l}\text { x夕 } \\
\text { 油x一 }\end{array}$ & $\overrightarrow{\text { 抽永出 }}$ & V，石 \\
\hline
\end{tabular}

* $\alpha, \alpha^{\prime}-7$ ソビイインブチロニトリル

第 3 表 VAc-VP 共重合物のアルカリタン化

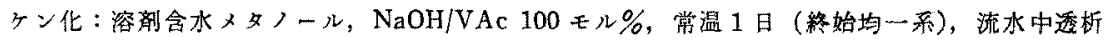

\begin{tabular}{|c|c|c|c|c|c|c|}
\hline 共重 合物 & & & v & 化 & & \\
\hline $\begin{array}{c}\mathrm{VP} / \text { 共重合) } \\
(モ \text { 物 }\end{array}$ & $(\%)$ & 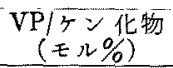 & 収 & $30^{\circ} \mathrm{C}$, 水中 & $\bar{p} *$ & $k^{\prime}$ \\
\hline 62.8 & 9. 56 & 55.3 & 80.0 & 0.1970 & $(6745)$ & 0.436 \\
\hline 7.7 & 1.64 & 5.6 & 77.0 & 0.0825 & 1660 & 0.702 \\
\hline
\end{tabular}

* 桜田式 $[\eta]=8.33 \times 10^{-4} \bar{p}^{0.62}$ (澷度 $\left.\mathrm{g} / l\right)$ によつた。

当社製， $\bar{p} \div 1,600$ または1,700のPVA 之VP系 重合物との混合水溶夜を常法に上りボウ硝凝固浴中湿 式紡系してえた $3.75 \mathrm{~d} \times 600$ フイラメント× 1 鉭のト ウを定長下で $235^{\circ} \mathrm{C} て ゙ 30$ 秒間熱処理するか，または $230^{\circ} \mathrm{C}$ で 30 秒間儿熱延伸した後, さらに $235^{\circ} \mathrm{C}$ で 30 秒間に 20\%熱收縮させたもの, 同様にして克た $3.35 \mathrm{~d}$ ×600フイラメント×1鉭のトウを上記と同一条件で熱 伸後延定長下で熱処理したものを用いた。

\section{2-3. アセタール化}

眽報》と同じ方法汇上り行なつた。アせタール化条件 をつぎ示す。

ホルマール化 (FA 化): ホルムアルデヒド (FA) 5 $\%, \mathrm{H}_{2} \mathrm{SO}_{4} 15 \%, \mathrm{Na}_{2} \mathrm{SO}_{4}$ (濃度変更), 浴比 $50: 1$, $60^{\circ} \mathrm{C}$ 大は $70^{\circ} \mathrm{C}, 1 \mathrm{hr} 。$

ベンザール化 $(\mathrm{BA}$ 化)：ペンズアルデヒド (BA)，カ チオン活性剂(ニッサンカチオン $\mathrm{BB}$, 主成分ドデシルト 3)メチルアンモニウムクロライド)(濃度変更), $\mathrm{H}_{2} \mathrm{SO}_{4} 4$
$\%$ ，直接染料として Nippon Fast Violet B B conc (C. I. Direct Violet 51) (D. V.), または Direct Green BC (C.I. Direct Green 6) (D. Gr.), Direct Blue 2B (C. I. Direct Blue 6) (D. BI.) 2\%あるい怰 Congo Red (C.I.Direct Red 28) $2 \%$ (または使用量变更)，ボり 硝 10\%を用い，浴比 50:1 で所定温度で所定時間染 色した後, 光電管比色計に上る残浴比色法で染着量 (mg 染料 $/ g$ 䋐維）を測定した。京た硫化染料として Sulphur Blue TFB (C. I. Sulphur Blue 7) (S. Bl.) $10 \%$, Sulphur Red Brown 6 R (C. I. Sulphur Red 1) (S. R.) $20 \%$ ，性 Sulphur Black B (C. I. Sulphur Black 1) (S. Black) $20 \% ， \mathrm{Na}_{2} \mathrm{~S}$ (染料々同量), 建染 染料として Indanthren Blue RSN (C.I. Vat Blue 4) (V.Bl.)，ま大惊 Indanthren Brilliant Green B(C.I. Vat Green 1) (V. Gr.) $4 \%, \quad \mathrm{NaOH}\left(40^{\circ} \mathrm{Be}^{\prime}\right) 8 \mathrm{ce} / \mathrm{l}$, ハイドロサルファイト $6 \mathrm{~g} / \mathrm{l}$ を用い浴比 $50: 1$ で所定 温度で所定時間染色し，し济り，空気酸化，水洗，つい 
第 4 表 PVP または VP-VAc 共重合ヶン化物混合紡系, 熱処理抢よびFA 化 PVA : $\bar{p} \fallingdotseq 1,600$, PVP : $K=30$, 共重合ヶン化物・VP $13.0 \%(5.6$ モル $\%$ ), FA化 : $60^{\circ} \mathrm{C}$, 染色: $80^{\circ} \mathrm{C}$. $1 \mathrm{hr}$ 。

\begin{tabular}{|c|c|c|c|c|c|c|c|c|c|c|c|c|c|c|c|}
\hline 漉 合 率 & $(\%)$ & 熱 & 処 & 理 & & & & $\mathrm{F}$ & & A & 化 & & & & \\
\hline$\frac{\text { VP系重合物 }}{\text { 全重合物 }}$ & $\begin{array}{l}\text { VP単位 } \\
\text { 全重合 } \\
\text { 物 }\end{array}$ & $\begin{array}{l}\text { 熱延 } \\
\text { 伸率 } \\
(\%)\end{array}$ & $\begin{array}{l}\text { 熱收 } \\
(\text { 樎率 } \\
(\%)\end{array}$ & $\begin{array}{c}\text { 水 } \\
\text { 軟化点 } \\
\left({ }^{\circ} \mathrm{C}\right)\end{array}$ & $\begin{array}{l}\mathrm{Na}_{2} \\
\mathrm{SO}_{4} \\
(\%)\end{array}$ & 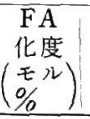 & $\begin{array}{l}\mathrm{N} \\
(\%) \\
\end{array}$ & $\begin{array}{l}100^{\circ} \mathrm{C} \\
\text { 水中収 } \\
\text { 縮率 } \\
(\%)\end{array}$ & 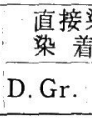 & $\begin{array}{c}\text { 染料 }(\mathrm{m} \\
\text { D. V. }\end{array}$ & $\begin{array}{c}\mathrm{mg} / \mathrm{g}) \\
\mathrm{D} . \mathrm{B} 1\end{array}$ & $\begin{array}{l}\text { 緎度 } \\
\text { (d) }\end{array}$ & $\left|\begin{array}{c}\text { 乾燥 } \\
\text { 強度 } \\
(\mathrm{g} / \mathrm{d})\end{array}\right|$ & $\mid \begin{array}{c}\text { 乾燥 } \\
\text { 伸度 } \\
(\%)\end{array}$ & $\mid \begin{array}{l}\text { 湿潤 } \\
\text { 強度 } \\
(\mathrm{g} / \mathrm{d})\end{array}$ \\
\hline- & - & - & 0 & 88 & 10 & 34.1 & - & 6.8 & 16. 4 & 2.3 & 0.7 & 4.96 & 4.08 & 27.7 & 3.24 \\
\hline PVP 5 & 5 & - & 0 & 79 & " & 35.1 & 0.66 & 8.8 & 17.9 & 10.6 & 1.7 & 4.63 & 3.80 & 27.7 & 2.74 \\
\hline " 10 & 10 & - & 0 & - & " & 32.8 & 1. 12 & 11.0 & 17.5 & 13.8 & 6.9 & 4.84 & t| 3.42 & 26.9 & 2.48 \\
\hline$" 1 \quad 20$ & 20 & - & 0 & 52 & 20 & 35.0 & 2. 12 & 12.0 & - & 17.4 & -1 & & & -1 & -1 \\
\hline $\begin{array}{l}\text { 共重合ヶン化 } \\
\text { 物 } 23.1\end{array}$ & 3 & - & 0 & 74 & 10 & 43.5 & - & 10.0 & 18. 7 & 13.9 & 1.0 & 3.01 & 3.49 & 33.2 & 2.50 \\
\hline- & -1 & 80 & 20 & 98 & 5 & 31.4 & - & 6.6 & 13.0 & - & 0.5 & 3.54 & $15.60 \mid$ & 22.8 & 3.53 \\
\hline PVP 5 & 5 & $135^{*}$ & " & 100 & $" \prime$ & 28.1 & - & 7.1 & 15.8 & - & 2.0 & 2.57 & 5.90 & 20.6 & 5.32 \\
\hline$" 10$ & 10 & $160 *$ & " & 96 & " & 30.1 & - & 6.9 & 15.4 & - & 7.0 & 2.48 & 35.52 & 19.8 & 34.40 \\
\hline " 20 & 20 & $166 *$ & $\prime \prime$ & 82 & "l & 30.4 & - & 9.5 & 16.5 & - & 13.1 & 1.92 & 4.60 & 18.4 & 44.05 \\
\hline $\begin{array}{l}\text { 共重合ヶン化 } \\
\text { 物 } 23.1\end{array}$ & 3 & $120 *$ & " & 82 & " & 37.0 & - & 7.6 & 18. 4 & 12.9 & - & 1.73 & 35.06 & 24.2 & 3.75 \\
\hline
\end{tabular}

\section{* 最大延伸率}

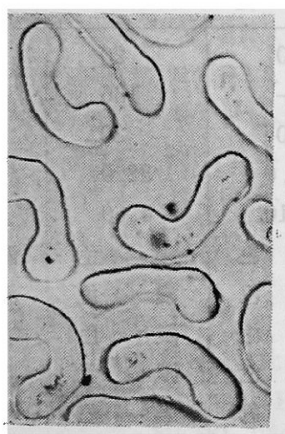

(i)

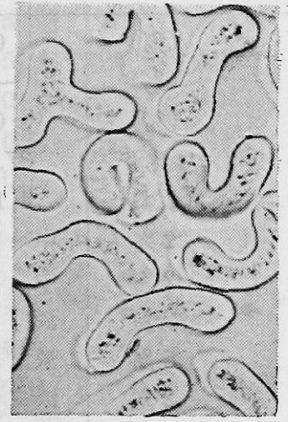

(ii)

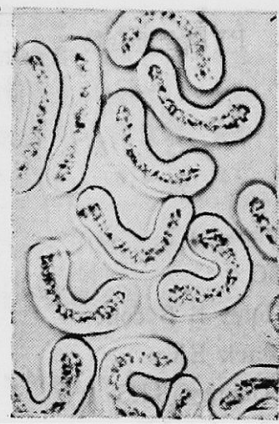

(iii)

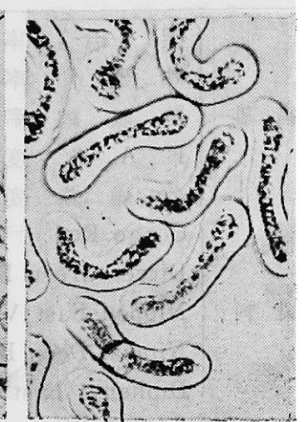

(iv)

Fig. 1. Cross sections of wet-spun, heat-treated and formalized fibers containing polyvinyl pyrrolidone.

Content : (i) $20 \%$, (ii) $10 \%$, (iii) $5 \%$, (iv) $0 \%$

でッーピング（セッヶン $5 \mathrm{~g} / \mathrm{l}, 80^{\circ} \mathrm{C}, 30$ 分）を行なつ た (2〜5項の\%はすべて緘維重量に対する\%を示す)。

\section{3. 実験結果および考察}

3-1. PVP またはVP-VAc 共重合物ヶン化物と PVA との混合紡糸によるビニロンの染色性の改良

PVP あるいはVP と VAc との共重合物, そのケン 化物と PVA との混合水溶液を湿式紡糸し, 定長下で熱 処理を行ならかあるいは紡系後熱延伸についで熱収縮を 行ない、さらにFA 化を行なつた結果を第 4 表に示し た。こ紡系原夜条件下では脱混合現象は認められない。 PVP の混合率が高いほど耐熱水性抢よび強度は低下す
る傾向が見ら机るが，とくに熱延伸についで熱収縮を行 なつた場合には PVP の混合率がかなり高くても沸トウ 水淤兑, かつ実用上十分な強度を示している。一方, PVP の混合率が高いほど直接染料に対する染着量は增 加して括り、また瀻維の断面は第 1 図に示すように内部 粒状構造が不明確となり，いわゆる無構造化9)の傾向を 示し, 第 2 図の上5に同一染着量の染色濃度 $(K / S)^{100}$ か 大となり，したがつて PVP の䃾合により染色濃度はい つそう顕著に向上している。共重合ヶン化物では, PVP の場合に比して, 強度, 而熱水性がやや低いが, 染色性 はやや良好である。

一般に水溶性重合物を混合紡系した PVA 系瀻維はこ 


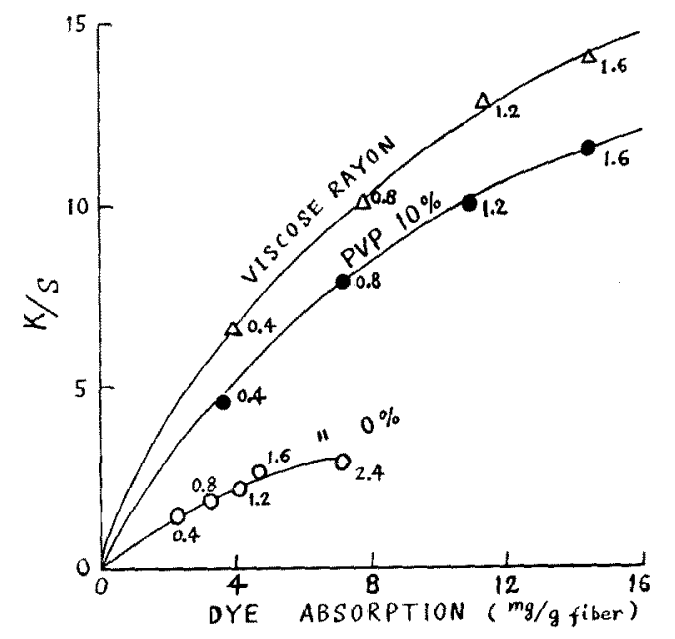

Fig. 2. Relation between dye absorption and depth of dyeings of wet-spun, hot-shrunk and formalized fibers containing polyvinyl pyrrolidone and of viscose rayon staple fiber.

Sample: Table 4 (Formalization : $\mathrm{Na}_{2} \mathrm{SO}_{4} 15 \%$, $70^{\circ} \mathrm{C}$ )

(PVP 0\%: Denier $3.54 \mathrm{~d}$, tenacity $5.60 \mathrm{~g} / \mathrm{d}$, $31.4 \mathrm{~mol} \%$ formalized.

PVP 10\%: Denier $2.48 \mathrm{~d}$, tenacity $5.52 \mathrm{~g} / \mathrm{d}$, $30.1 \mathrm{~mol} \%$ formalized.

Viscose rayon : Denier $3.06 \mathrm{~d}$, tenacity $2.54 \mathrm{~g}$ /d, -

Dyeing : Congo Red $0.4,0.8,1.2,1.6$ and 2.4 $\%, 80^{\circ} \mathrm{C}, 2 \mathrm{hrs}$.

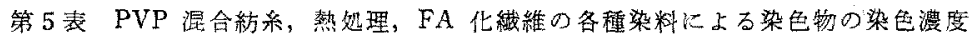
(ピスコースレーシンと比皎)

試料：第 4 䠔，ただし FA 化条件 $\mathrm{Na}_{2} \mathrm{SO}_{4} 15 \%, 70^{\circ} \mathrm{C}$ 。

\begin{tabular}{|c|c|c|c|c|c|c|c|c|}
\hline & 試 & 料 & \multicolumn{4}{|c|}{ FA 化 $E^{n}=F V$} & \multicolumn{2}{|c|}{$\begin{array}{l}E x a-\pi v \\
-\Xi y \cdot x>\end{array}$} \\
\hline & (混合率 PVP/全重畣物 & $(\%)$ & \multicolumn{2}{|c|}{0} & \multicolumn{2}{|c|}{20} & \multicolumn{2}{|c|}{-} \\
\hline & 熱 延 伸 蜜 & $(\%)$ & \multicolumn{2}{|c|}{ - } & \multicolumn{2}{|c|}{166} & \multicolumn{2}{|c|}{ - } \\
\hline 試料 繊 唯 & 熱 収 縮 率 & $(\%)$ & \multicolumn{2}{|c|}{0} & \multicolumn{2}{|c|}{20} & \multicolumn{2}{|c|}{ - } \\
\hline & F A 化 森 & $(€ \mu \%)$ & \multicolumn{2}{|c|}{37.0} & \multicolumn{2}{|c|}{32.0} & \multicolumn{2}{|c|}{ - } \\
\hline & 乾獎 強 度 & $(\mathrm{g} / \mathrm{d})$ & \multicolumn{2}{|c|}{ 4. 10} & \multicolumn{2}{|c|}{ 4. 60} & \multicolumn{2}{|c|}{2.54} \\
\hline \multirow{5}{*}{ 㨁 接 染 料 } & Congo Red & $2 \%$ & 中 & & 濃 & & 溧 & \\
\hline & Direct Green $\mathrm{BC}$ & $2 \%$ & 中马 & 色 & 濃 & 色 & 澧 & 色 \\
\hline & Nippon Fast Violet B B conc. & $2 \%$ & 淡 & 巴 & 濃 & 色 & 濃 & 色 \\
\hline & Nippon Deep Black EX & $5 \%$ & 淡 & 色 & 整 & 色 & 濃 & 色 \\
\hline & I Diphenyl Fast Orange $3 \mathrm{RS}$ & $2 \%$ & 淡 & 色 & 濃 & 色 & 濃 & 色 \\
\hline \multirow{2}{*}{ 酸 性 染 料 } & $\int$ Acid Brilliant Scarlet $3 \mathrm{R}$ & $2 \%$ & 涪 & 染 & 淡 & 色 & 污 & 染 \\
\hline & Rocceline NS & $2 \%$ & 中 & 色 & 澹 & 危 & 淡 & 色 \\
\hline 含金属染料 & Irgalan Brown $2 \mathrm{RL}$ & $2 \%$ & 中 & 㑇 & 濃 & 色 & 活 & 染 \\
\hline \multirow[t]{2}{*}{ 酸性媒染染䉼 } & Sunchromine Brown $\mathrm{RH}$ & $2 \%$ & 㗵 & 色 & かな & 濃色 & 活 & 染 \\
\hline & Sulphur Blue TFB & $10 \%$ & 中 & 色 & 濃 & 色 & 濃 & 色 \\
\hline \multirow[t]{2}{*}{ 硫 化染 料 } & Sulphur Black BX & $10 \%$ & 淡 & 色 & 濃 & 色 & 溍 & 色 \\
\hline & Sulphur Red Brown $6 \mathrm{R}$ & $20 \%$ & 淡 & 无 & 濃 & 色 & 濃 & 色 \\
\hline \multirow{2}{*}{ 建染染料 } & I Indanthrene Blue RSN & $4 \%$ & 中 & 色 & 蓝 & 色 & 濃 & 色 \\
\hline & Mikethrene Scarlet G & $4 \%$ & 中 & 色 & 濃 & 色 & 惯 & 色 \\
\hline 分 散 染 料 & Diacelliton Fast Brilliant Blue BF & $2 \%$ & 中 & 色 & 濃 & 鱼 & 涯 & 染 \\
\hline
\end{tabular}

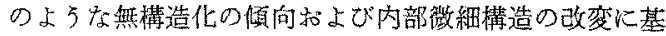
つく染着性の向上の傾向を示すことが知ら机ているが1， PVP の場合に恃ず報告したポリアクリルアミドあ るい部分カルバモイルェチル化 PVA の場合》゙り染 着性の向上が顕著である。第 5 表上り各種染料汶する 染着性が普通ピニ仕り著しく向上していることは明 らかである。ビスコース・スフとの比較に括いてを直
接，硫化，建染々料汇は十分匹敵しらる染色性を示し， セりトン染料，古るいは一部の酸性，酸媒，含金属染料 に対してもはるか炕良好な染色性を示している。W， Scholtan $^{3)}$ 扰よび J.W. Breitenbach ら) により PVP

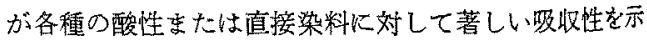

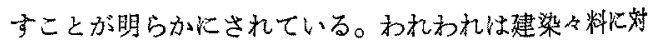
する PVP の親和性を確かめるだめビスコース・スフの 
染浴汶対して PVP, PVA 烛じめ数種の水溶性重合物 添加して去九らの染色妨害效果索比較した。その結果 第6 表江示主。これらの乐溶性重合物の中で PVP が 建染及料のロイコ体に対してもつとも大きい親和性定示 している。PVP 類を混合紡系した織維の染色性に打い ては前述した無構造化, 内部濑細㯕造の改变などの効果 の任か，さらに PVP の染料親和性に上る效果が付加さ れているすのと考党られる。

つぎ弹性回得性をる改良するため BA 化在行なっ

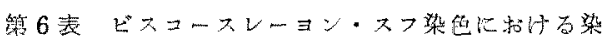

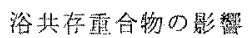

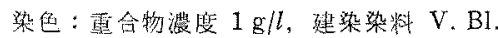
$4 \%$, 浴比 $100: 1,60^{\circ} \mathrm{C}, 1 \mathrm{hr}_{0}$

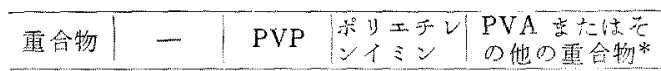

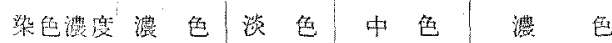

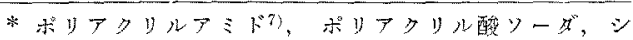

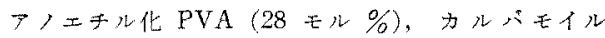
エル化 PVA $(30 \pm ル \%)^{7}$ 。

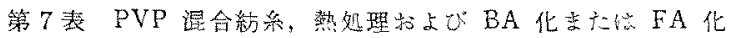

PVA : $\bar{p}=1,600$, 架色: $90^{\circ} \mathrm{C}, 1 \mathrm{hr}$

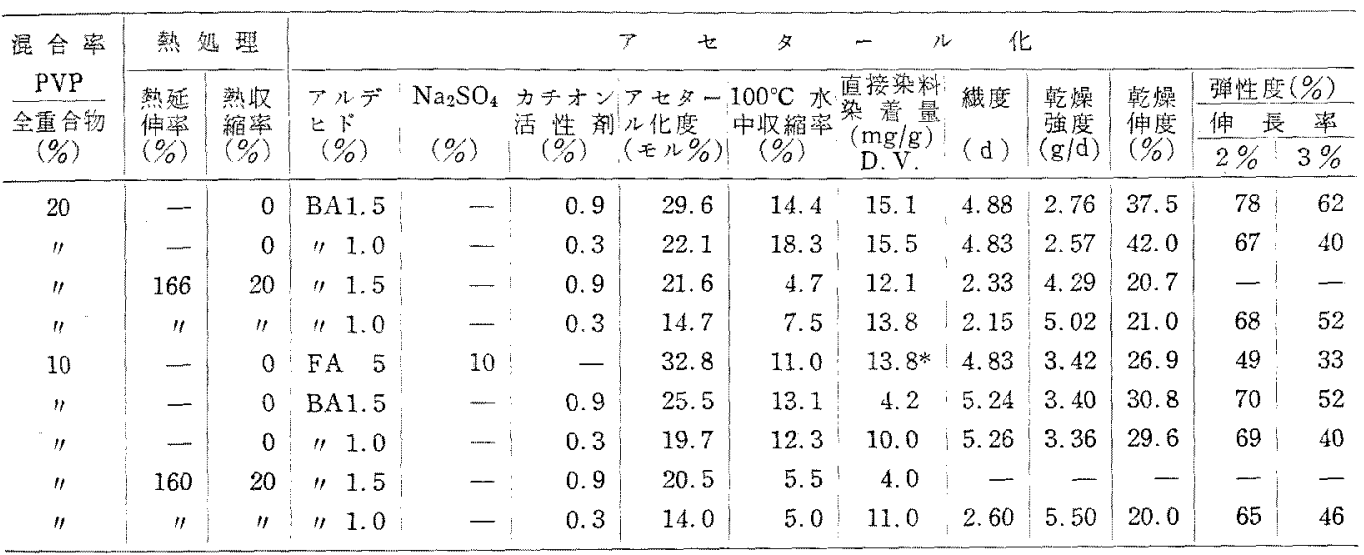

$* 80^{\circ} \mathrm{C}, 1 \mathrm{hr}$ 染色。

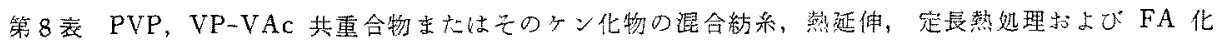
(エジプト綿に比較)

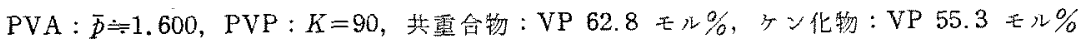
FA 化: $\mathrm{Na}_{2} \mathrm{SO}_{4} 0 \%, 60^{\circ} \mathrm{C}$

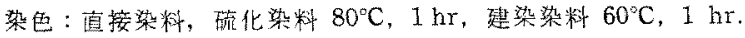

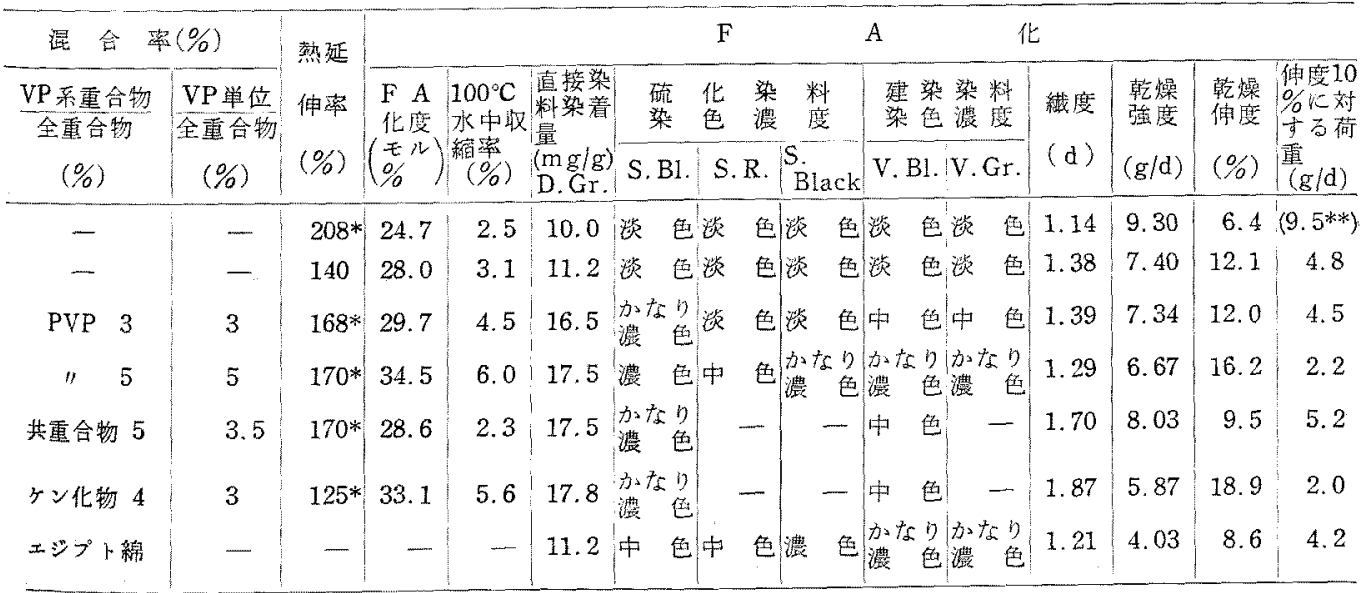

* 最大延伸率

***外插傋 
た結果を第 7 表に示した。堆延伸についで熱取縮を行な

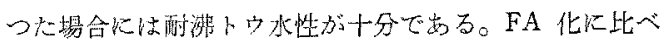

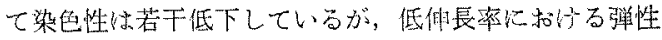
回復生が垦好である。

3-2 PVP，VP-VAc 共重合物またはそのケン化物 とPVAとの混合紡系による綿混用ビニロン

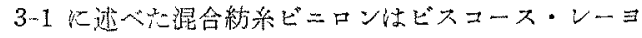
ンに類似した染色性を示し，これより強度がはるが高

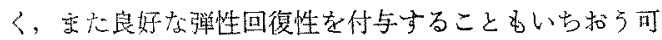
能であり，整好理による着色も医とんど諗められない で, とくにビスコース・レーシンとの泿紡に適している と洘えられる。しかし綿と混紀した場合にはこれらの緎

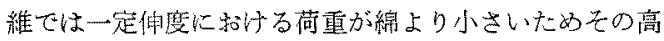
强力が有效に利用され之ないと考之られ，荷重伸長関係 安考虙した上て染色性を論ずる必要がある。そこで，

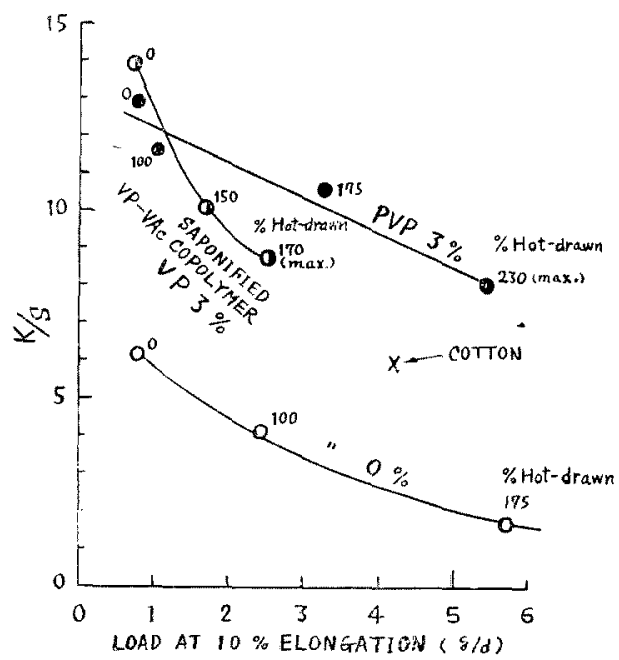

Fig. 3. Relation between load at $10 \%$ elongation and depth of dyeings of wet-spun, hot-drawn, heat-treated and formalized fibers containing polyvinyl pyrrolidone or saponified vinyl acetate - vinyl pyrrolidone copolymer.

Polyvinyl alcohol : $\bar{p} \div 1,700$, Polyvinyl pyrrolidone : $K=60$, Saponified vinyl acetate-vinyl pyrrolidone copolymer: vinyl pyrrolidone unit $55.3 \mathrm{~mol} \%$, Formalization: $\mathrm{Na}_{2} \mathrm{SO}_{4} 0 \%, 60^{\circ} \mathrm{C}$, Dyeing: Sulphur Blue TFB $10 \%, 80^{\circ} \mathrm{C}, 1 \mathrm{hr}$,

PVP，むるいはVPとVAcとの水溶性共重合物また はそのケン化物を混合紡系した絨維について熱延伸後定 長熱㚮理についでFA 化を行なつた結果を第8表括よ び第 3 図に示した。一般に熱延伸率が高いはと強度が增 加し，伸度は低下し，一定伸度に詨する荷重汃堆加し， また染色性は低下する傾向を示して牤り，一方 PVPの
混合率が言いはど嵲の傾向を示している。同程度の一定 伸度に対する街重に括いて染色性を比艾した場合 PVP の効果は明瞙に認められる。染料によつて多少の童はま るが，荷重伸厓関係老考虑した場合にす綿にほぼ近い染

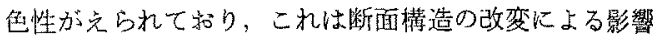
b考光られるが，とくに PVP の染料親和性が染色性に 対してかなり支配的に影響しているた心と考克られる。 共望合物ではPVPの場合に類似した効果が見られるが， これに比してそのケン化物では熱䔉伸性, 強度, 一定伸 座に刘等る荷重衿よび酎熱水性の低下が大きく，一定伸 展に対する荷重の高い埸合で比較する上染色性が少つて いる。これはタン化物の力が PVA との相互作周が大き く、結晶性の低下に対する管与が大きいのに対し，PVP， VP と VAc との共重合物ては PVA との相互作用が小 で，PVA の結晶性に大きい影響を与えずに染色性を改 良しうることを示していると考光られる。したがって荷 重伸舆関係を考慮すればビニルアルコールの其重合体を 朋いるよりビニルアルコール基を含有しない水溶性重合 物を用いる力が有效であるとい充るようで岁る。

\section{4. 総括}

ビニロンの染他性を改良するためPVA と PVP, VAc

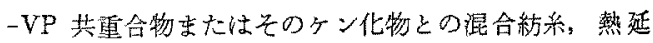
伸，熱処理括よび FA または BA 化を行ない，染色性 をはじめ支の他の諸牲質を測定した。PVPの混合紡系 に上りピニロンの各種染料々くに直接, 醇化, 建染各染 料に対する染色性は顕著に向上する。一般に水溶性重合

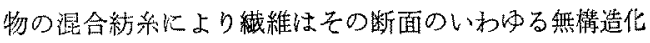
の傾向执よび內部微細構造の改変により染着性そのもの も若干向上する傾向を示劣が，PVP の場合にはこれら の效果の活加さらに PVP の染料親和性に上る效果が付 加されていることを確かめた。をたこれらの㵶維はいわ ゆる動物質化の場合と買なり，熱処理に上る着色の增加 が注とんど認められずまた值接，硫化，建染の各染料比

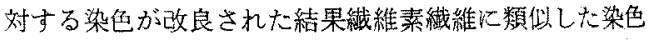
性を示すよらになるのでこれとの混紡汇道すると考方ら れる。とく綿との混紡を考えた場合には荷重伸長関係

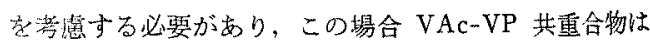
PVPに類似した効果を与支るか，これに比してそのケン 化物では熱延体性，強度扣よび一定伸度に対する荷棉の 低下艻大きく，一定伸度に対する比较的高い荷重に拈い て染色性を比較すると劣つている。したがつて PVP たは水溶性 VAc-VP 共重合物を用いることにより線に 類似した荷重伸長関係と染色性とを示すピニロンが党ら れた。

お方りに本研究にさいしご指導を賜わつた当社研究所 
長大杉鉄郎博士, 松本昌一博士ならびに田辺健一博士に 㳭く感謝する。な抬本研究の概要は昭和 34 年 4 月, 日 化第 12 年会で講演した。

\section{文献}

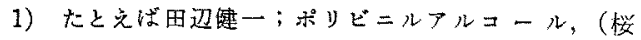
田一郎緛)，p.403，高分子学会 (1956)

高分子展望第 15 箱 p. 103, 高分子化学刊行会 (1959)

川上博；ポリビニルアルニール（兴田一郎編）p. 131 高分子学会 (1956)

2) W. Reppe ; Angew. Chem., 65, 577 (1953)

3) W.Scholtan; Makromol.Chem., 11, 131 (1953)

4) J.W.Breitenbach, E. Wolf ; Makromol.Chem.,
$18 / 19,217(1956)$

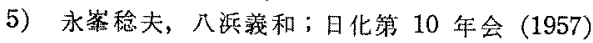

6)大杉鉄郎，松本昌一，由辺健一，平野豊；日本特 許 246,168 公告昭 $32-10362$

大杉鉄郎，松本昌一，田辺健一，大野淮次，平野 㽬；日本特許公告玿 33-10669

大杉鉄郎，松本昌一，田辺健一，秈林筧治，平野 豐, 日本特許公告昭 34-3389

7）菘林寛治，田辺煡一；工化，62，1753 (1959)

8）田辺健一, 大埋康次；織学誌，13，258 (1956)

9)平林潅; 日本化学䋐維研究所糬演集, 第 12 集, p. 9 (1955)

10)田辺健一, 那須野炤文; 絾学誌, 16，235(1960)

$$
\begin{aligned}
& \text { ポリビニルアルコールと塭基性重合物 } \\
& \text { エマルションとの混合紡糸 }
\end{aligned}
$$

$$
\text { 會数レイヨン株式会社 松 林 寬 治・平野豊 }
$$

\section{THE SPINNING OF A POLYMER BLEND CONSISTING OF POLYVINYL ALCOHOL AND BASIC POLYMER LATEX (I) (II)}

By Kanji Matsubayashi and Yutaka Hirano

(Research Laboratory, Kurashiki Rayon Co. Ltd., Kurashiki

City, Okayama Prefecture, Japan)

\section{THE PREPARATION OF VINYLPYRIDINE COPOLYMER LATEX}

In order to improve the dyeability of vinylon, the spinning of polymer blend consisting of polyvinyl alcohol and basic polymer latex has been studied. In this paper, the results on emulsion copolymerization of vinylpyridine and divinylbenzene or other monomers under various conditions and on stability of the latices or of the spinning solutions containing the latices were described. The latices containing anionic surfactant generally have a tendency to be coagulated at elevated temperature and the spinning solutions cotaining the latices were not sufficiently stable under an usual spinning condition, particularly in the case of dry spinning. On the other hand, the copolymer latices having relatively higher stability were obtained by emulsion polymerization in the presence of various acids or aminoacetalized polyvinyl alcohol, and the spinning of the polymer blend was able to be carried out without any trouble. The results on stability of the latices seem to be explained by the hydrophilic property of the particles.

\section{THE SPINNING OF POLYVINYL ALCOHOL AND VINYLPYRIDINE COPOLYMER LATEX}

The wet-or dry-spinning of polymer blend consisting of polyvinyl alcohol and vinylpyridine 